\title{
Molluscum contagiosum treated with systemic aciclovir: a case report
}

\author{
Marco Luigi Castelli \\ Department of Otorhinolaryngology, Ospedale SS Annunziata, Savigliano 12038, ASL CN1, Italy
}

\begin{abstract}
Introduction: Molluscum contagiosum is a common infection which can be severe in immunocompromised patients. New treatment modalities may be useful in such patients when the lesions keep recurring despite local treatment.
\end{abstract}

Case report: We present a case of recurrent molluscum contagiosum despite re-infection via self-inoculation being prevented by prompt removal of any new lesions. Recurrence only stopped when systemic aciclovir was administered.

Conclusion: Further research is desirable to assess the real usefulness of systemic antiviral therapy for recurrent molluscum infection resistant to local therapy.

\section{Introduction}

Molluscum contagiosum virus is an important human skin pathogen, it is often considered to be innocuous but the skin lesions can be very persistent and cause disfigurement. It is a common condition in children while in adults it can be sexually transmitted [1]. Extensive infection can be due to immunodeficiency. Traditionally, the typical umbilicated lesions are either curetted or removed by chemicals but treating patients with multiple lesions, especially children, may be difficult and complications of local treatment include infection and scarring [2]. Recently, immune-modulating and antiviral therapies have been tried as an alternative or as adjuvant cures to traditional ablative therapies [3]. Many agents inhibiting the viral DNA polymerase are used against double-stranded DNA viruses but none have been approved to treat molluscum contagiosum [4]. We present a case report of a patient who had persistently recurring lesions until he was successfully treated with systemic acyclovir.

\section{Methods and results: Case report}

Male, 50 years old, presented with a palpable subcutaneous lump 5 millimeters in size, soft and not tender on palpation. The lesion became progressively raised involving the epidermis and umbilicated. The patient ignored the physician's advice and squeezed the lesion himself releasing a small amount of white caseous material; the lesion subsequently disappeared but many lesions typical of molluscum contagiosum appeared nearby. These were inspected daily and removed with a forceps as soon as they were seen and diagnosis was confirmed by histology which also confirmed that the lesions were removed completely down to the dermal layer with disease free margins. Such lesions kept recurring for three months even when their prompt removal should have prevented self-inoculation to the surrounding areas. Anamnesis confirmed that none of the patient's contacts/family was infected and could not be the cause of the recurrences. HIV, HBV and HCV infection was ruled out by serology; he was eventually administered acyclovir tablets $200 \mathrm{mg}$ orally 5 times a day for 5 days and the lesions immediately stopped recurring.

\section{Discussion}

Molluscum contagiosum virus is known to spread by contact with lesions. It is generally believed that the virus stays localized in the epidermal layers, where it produces a typical, complex hyperproliferative lesion with an abundance of virus particles [3], but in the case above, the suspicion that virus had spread to the subcutaneous tissues made us believe that systemic therapy would be more effective than local therapy as the former could reach deeper tissues better. There are only a few reports of Cidofovir used mainly topically in the literature [5-7]. Systemic therapy was therefore started: a common antiviral drug was chosen though it has not been used for such purpose previously. The therapy administered had no adverse effects, it lasted only 1 week and the patient has been free from disease after 2 years of follow up.

\section{Conclusion}

The purpose of this case report is to promote further research: we think that the use of a brief systemic therapy with acyclovir could be investigated to assess its usefulness in patients with prolonged recurrent lesions. This could be of particular benefit to immunosuppressed patients.

\section{Acknowledgements}

We thank Dr. Dong Ching Chiu for advices and revision.

\section{References}

1. Hanson D, Diven DG (2003) Molluscum contagiosum. Dermatol Online $J$ 9: 2 [Crossref]

2. Hancox JG, Jackson J, McCagh S (2003) Treatment of molluscum contagiosum with the pulsed dye laser over a 28-month period. Cutis 71: 414-416. [Crossref]

Correspondence to: Marco Luigi Castelli, Via Barbacana 18 A, Cavallermaggiore, 12038, Italy, Tel: +39335 5650647; E-mail: casterr@infinito.it

Key words: Molluscum contagiosum; aciclovir

Received: July 15, 2015; Accepted: August 10, 2015; Published: August 14, 2015 
3. Chen X, Anstey AV, Bugert JJ (2013) Molluscum contagiosum virus infection. Lancet Infect Dis 13: 877-888. [Crossref]

4. Dropulic LK, Cohen JI (2010) Update on new antivirals under development for the treatment of double-stranded DNA virus infections. Clin Pharmacol Ther 88: 610-619. [Crossref]

5. McElhiney LF Pharmd Rph (2006) Topical Cidofovir for Treatment of Resistant Viral Infections. Int J Pharm Compd 10: 324-328. [Crossref]
6. Toutous-Trellu L, Hirschel B, Piguet V, Schiffer V, Saurat JH, et al. (2004) Treatment of cutaneous human papilloma virus, poxvirus and herpes simplex virus infections with topical cidofovir in HIV positive patients. Ann Dermatol Venereol 131: 445-449. [Crossref]

7. Zabawski EJ Jr (2000) A review of topical and intralesional cidofovir. Dermatol Online $J$ 6: 3. [Crossref]

Copyright: (C2015 Castelli ML. This is an open-access article distributed under the terms of the Creative Commons Attribution License, which permits unrestricted use, distribution, and reproduction in any medium, provided the original author and source are credited. 